\title{
Ribavirin Treatment in Patients with Chronic Hepatitis C Infection Who Had Renal Transplantation
}

\author{
Cetin Karaca $^{a}$ Fatih Besisik $^{a} \quad$ Filiz Akyuz $^{a}$ Dinc Dincer ${ }^{a}$ Mehmet Sukru Sever ${ }^{b}$ \\ Atilla Okten ${ }^{a}$ \\ Departments of a Gastroenterohepatology and ${ }^{\mathrm{b}}$ Nephrology, Istanbul University, Istanbul Medical Faculty, \\ Istanbul, Turkey
}

\begin{abstract}
Chronic hepatitis $\mathrm{C}$ infection, which is common in patients with chronic renal failure on hemodialysis, is also an important cause of morbidity and mortality after renal transplantation. Immunosuppressive medications given in the post-transplant period may hasten damage to the liver and increase hepatitis $\mathrm{C}$ virus (HCV) replication [1]. Interferon- $\alpha$ can be used in chronic hepatitis $C$, but is not appropriate in the post-transplant period because it can cause rejection of the transplanted kidney [2]. To date, there is no medication that can be used to treat chronic hepatitis $\mathrm{C}$ in the post-transplant period. In this study, we investigated ribavirin, in renal transplantation patients with hepatitis $\mathrm{C}$.
\end{abstract}

We investigated $5 \mathrm{HCV}$-infected patients ( 3 males) between the ages of 25 and 50 years who had undergone renal transplantation. They had persistently elevated transaminase levels. Four of the patients had living-donor transplants and 1 had a cadaveric-donor transplant. All of the patients were on cyclosporine-based immunosuppressive treatment. Anti-HCV (by UBI EIA 4.0; Organon Teknika) and HCV RNA (with PCR) were positive in all patients. Genotypes were $1 \mathrm{~b}$ in all cases. After the diagnosis of chronic hepatitis $\mathrm{C}$ infection had been established by liver biopsy, ribavirin was given $800 \mathrm{mg}$ p.o. dai- ly. In the first month of the therapy, the patients were examined weekly for side effects including hemolysis. Transaminase levels were checked monthly. Normalization of the transaminase levels was accepted as a biochemical response, and HCV RNA negativity was accepted as a virological response.

Ribavirin therapy was given for 3-30 months. Pre- and post-treatment median aspartate aminotransferase, alanine aminotransferase, hemoglobin, and hematocrit levels were 84-49 U/1, 83-65 U/l, 12.5-10 g/dl, and $36-32 \%$, respectively. None of the patients cleared HCV RNA. In 1 patient the transaminase level decreased to the normal range. In 3 patients, treatment was ceased because their hemoglobin and hematocrit levels decreased gradually despite decreasing their ribavirin dose to $400 \mathrm{mg}$ daily. One patient was given packed red blood cells.

In Turkey, hemodialysis and renal transplantation patients are the groups among whom HCV is the most common [3]. Interferon increases the risk of rejection in renal transplant patients because it is a strong immunomodulatory drug enhancing $\mathrm{T}$ lymphocyte-related cytotoxicity and natural killer functions. We obtained no virological response to ribavirin monotherapy, contrary to what is reported in the literature [4]. How- ever, there was a tendency to a decrease in transaminase levels compared to the values at the beginning of therapy, and in only 1 patient did they decrease to the normal range. In these patients, although ribavirin was used at lower doses, signs of hemolysis were evident and symptomatic.

In conclusion, ribavirin treatment in patients with chronic hepatitis $\mathrm{C}$ infection who have undergone renal transplantation is ineffective and its hemolytic effect is predominant and dose limiting.

\section{References}

1 Lau JY, Davis GL, Brunson ME, et al: Hepatitis $\mathrm{C}$ virus infection in kidney transplant recipients. Hepatology 1993;18;1027-1031.

$\checkmark 2$ Min $\mathrm{AD}$, Bodenheimer HC: Does interferon precipitate rejection of liver allografts? Hepatology 1995;22:1333-1335.

3 Besisık F, Okten A, Sever M: Renal transplantasyon yapılmıs hastalarda anti-HCV seropozitifliğinin klinik önemi. Klimik 1994;6:31-34.

-4 Garnier JL, Chevallier P, Dubernard JM, et al: Treatment of hepatitis $C$ virus infection with ribavirin in kidney transplant patients. Transplant Proc 1997;29:783.

\begin{tabular}{ll}
\hline KARGER & $\begin{array}{l}\text { ( ) 2005 S. Karger AG, Basel } \\
\text { 0253-4886/05/0222-0113\$22.00/0 }\end{array}$ \\
$\begin{array}{l}\text { Fax +4161306 12 34 } \\
\begin{array}{l}\text { E-Mail karger@karger.ch } \\
\text { www.karger.com }\end{array}\end{array}$ & $\begin{array}{l}\text { Accessible online at: } \\
\text { www.karger.com/dsu }\end{array}$
\end{tabular}

Cetin Karaca

Department of Internal Medicine, Hepatology Division Istanbul University, Istanbul Medical Faculty, Çapa

TR-34390 Istanbul (Turkey)

Tel. +90 21242417 00, Fax +90 21263197 43, E-Mail filizakyuz@hotmail.com 